\title{
PENGARUH KEDISIPLINAN TERHADAP PENINGKATAN PRESTASI BELAJAR PESERTA DIDIK PADA MATA PELAJARAN PKn DI SMK PASUNDAN 1 SUBANG
}

\author{
Cahyono, M.Pd \\ Dosen STKIP Subang \\ yonjun85@gmail.com
}

\begin{abstract}
Discipline is berperanguh to increased student achievement. This study aims to collect information on students' disciplinary effect on student achievement in the subjects of Civics at SMK Pasundan 1 Subang. Using the theory of discipline (Maman Rachman and A. Kosasih Djahiri) and the theory of learning achievement (Moh. Surya). By using a quantitative approach. Penenlitian sample as many as 108 students and 2 teachers Civics. The results showed that the discipline of the students have a significant influence on the improvement of student achievement that is, True 0, 832. It can be concluded that the higher discipline learners, it will be a good learning achievements of learners, especially on the subjects PPKn in SMK Pasundan 1 Subang
\end{abstract}

Keywords: Discipline, Learning Achievement and Citizenship Education

\section{ABSTRAK}

Disiplin sangat berperanguh terhadap peningkatan prestasi belajar siswa. Penelitian ini bertujuan untuk menggali informasi tentang pengaruh kedisiplinan siswa terhadap prestasi belajar siswa pada mata pelajaran PKn di SMK Pasundan 1 Subang. Dengan menggunakan teori kedisiplinan (Maman Rachman dan A. Kosasih Djahiri) dan teori prestasi belajar (Moh. Surya). Dengan menggunakan pendekatan kuantitatif. Sampel penenlitian sebanyak 108 orang siswa dan 2 orang guru PKn. Hasil penelitian menunjukan bahwa kedisiplinan siswa memberikan pengaruh yang signifikan terhadap peningkatan prestasi belajar siswa yaitu sebenar 0, 832. Dapat disimpulkan bahwa semakin tinggi kedisplinan peserta didik, maka akan semakin bagus pula prestasi belajar peserta didik khususnya pada mata pelajaran PPKn di SMK Pasundan 1 Subang.

Key Words: Disiplin, Prestasi Belajar, dan Pendidikan Kewarganegaraan

\section{PENDAHULUAN}

Disiplin dapat diartikan sebagai suatu bentuk kesadaran diri yang muncul dari batin yang terdalam berupa dorongan untuk mengikuti dan menaati peraturan-peraturan dan nilai-nilai serta hukum yang berlaku dalam suatu lingkungan tertentu. Dalam pendidikan disiplin menjadi sarana yang sangat penting untuk membantu para peserta didik agar berprestasi. Dalam mendidik, disiplin memiliki pernan yang sangat penting dalam mempengaruhi, mendorong, mengendalikan dan mengubah, serta membentuk perilaku peserta didik agar sesuai dengan nilai-nilai yang ditanamkan. Disiplin di sini diartikan 


\section{Didaktik : J urnal Pendidikan Guru Sekolah Dasar, ISSN : 2477-5673 \\ Sekolah Tinggi Keguruan dan Ilmu Pendidikan Subang Volume I Nomor 2, J uli 2016}

sebagai bentuk ketaatan pada peraturan sekolah. Dari sini semuanya bermula, sebelum disiplin diterapkan perlu dibuat peraturan atau tata tertib yang benar-benar realistic. Namun masih banyak sekolah yang mutunya rendah baik ditinjau dari nilai-nilai peserta didik, kinerja personal sekolah, maupun prestasi belajar para peserta didiknya. Salah satun penyebabnya masih belum jelasnya peraturan yang dibuat dan dijalankan oleh sekolah tersebut, sehingga tidak mudah diaplikasikan, atau buruknya pengawalan penerapan peraturan itu tidak bisa berjalan secara optimal.

Kebiasaan disiplin marupakan kebiasaan yang positif yang harus dikembangkan dalam berbagai lingkungan kehidupan, baik lingkungan keluarga, sekolah, masyarakat, bangsa dan negara. Salah satu lingkungan yang efektif dalam membentuk kedisiplinan peserta didik yaitu dilingkungan sekolah. Hal ini sesuai dengan pendapat Maman Rachman (1999) yang mengemukakan bahwa tujuan disiplin sekolah adalah: (1) memberi dukungan bagi terciptanya perilaku yang tidak menyimpang, mendorong peserta didik melakukan yang baik dan benar, (3) membantu peserta didik memahami dan menyesuaikan diri dengan tuntutan lingkungannya dan menjauhi melakukan hal-hal yang dilarang oleh sekolah, dan (4) peserta didik belajar hidup dengan kebiasaan-kebiasaan yang baik dan bermanfaat baginya serta lingkungannya. Hal tersebut sesuai dengan pernyataan Erwin S. (2015: 68) yang menyatakan sekolah merupakan tempat atau wadah untuk mengembangkan atau membentuk karakter warga negara atau (Civic Disposition) peserta didik.

Dengan terbentuknya karakter warga negara (civic disposition) yang salah satunya adalah memiliki sikap kedisiplinan pada diri peserta didik, akan memudahkan para peserta didik dalam meraih pretasi baik dilingkungan sekolah maupun dilingkungan masyarakat. Prestasi dilingkungan sekolah salah satunya berupa prestasi belajar yang merupakan hasil dari suatu kegiatan belajar. Sebagaimana disampaikan oleh Moh. Surya (1985:174) yang mengemukakan bahwa, "Prestasi belajar adalah seluruh kecakapan hasil yang dicapai yang diperoleh melalui proses belajar di sekolah yang dinyatakan dengan nilai-nilai prestasi berdasarkan hasil tes belajar".Dengan demikian, peserta didik akan mencapai sebuah prestasi apabila ia mengalami proses belajar yang teratur, konsisten, dan berkesinambungan.

Prestasi belajar akan dapat diraih dengan kerjakeras, dan belajar teratur sesuai dengan instruksi dan peraturan yang berlaku baik dilingkungan sekolah maupun lingkungan masyarakat. Selain hal tersebut prestasi belajar tentunya dipengaruhi oleh beberapa faktor diantaranya faktor keluarga, lingkungan, sekolah dan masyarakat. Indikator prestasi yang dicapai oleh peserta didik dalam mata pelajaran PKn lebih menitikberatkan pada aspek nilai, moral, dan norma sebab Mata Pelajaran PKn itu mengarahkan kepada pembinaan moral, sebagaimana yang dikemukakan oleh A. Kosasih Djahiri (1993:13) sebagai berikut:

"PKn menyiapkan, membina dan mengembangkan pengetahuan serta kemampuan dasar peserta didik yang berkenaan dengan hubungan antara warga negara dengan negaranya. Melalui program ini, peserta didik akan 


\section{Didaktik : J urnal Pendidikan Guru Sekolah Dasar, ISSN : 2477-5673 \\ Sekolah Tinggi Keguruan dan Ilmu Pendidikan Subang \\ Volume I Nomor 2, J uli 2016}

dibina menjadi warga negara Indonesia yang baik dan berjiwa Pancasila yakni: warga negara yang paham dan sadar serta mau dan mampu melaksanakan hak dan kewajiban dan tugas tanggung jawab dirinya, masyarakat dan pemerintah negaranya, rela berkorban demi bangsa negaranya serta siap dalam setiap kegiatan yang layak".

Dari pendapat tersebut di atas, jelas bahwa Mata Pelajaran PKn harus mampu mengarahkan dan membina prestasi belajar peserta didik berupa penumbuhan sikap disiplin, tanggungjawab, mandiri, dan berakhlak mulia serta berkarakter baik. Disiplin perlu diterapkan dalam berbagai aspek kehidupan guna mencapai prestasi belajar yang optimal. Seseorang dapat dikatakan disiplin apabila ia melakukan atau mengerjakan sesuatu pekerjaan dengan tertib dan teratur sesuai dengan waktu dan ketentuan tanpa paksaan dari siapapun. Disiplin harus terwujud dalam kehidupan keluarga, masyarakat, dan sekolah berupa disiplin dalam belajar.

Apakah kedisiplinan yang tinggi dapat menunjang tercapainya prestasi belajar yang baik? Hal itu belum diketahui secara jelas sementara prestasi yang baik tentunya membutuhkan disiplin yang tinggi dalam belajar. Selain itu, disiplin merupakan bagian dari faktor pendukung dalam proses belajar mengajar dalam rangka mencapai prestasi yang baik. Penelitian ini bertujuan untuk menemukan jawaban yang berkenaan dengan pengaruh kedisiplinan peserta didik terhadap peningkatan prestasi belajar pada mata pelajaran PKn di SMK Pasundan I Subang.

Hilgard dalam Abin Syamsudin Makmun, (2004: 157), menyatakan bahwa "belajar merupakan suatu proses perubahan prilaku atau pribadi seseorang berdasarkan praktik atau pengalaman tertentu". Hal ini senada dengan pendapat Gage dalam Martinis Yamin (2005: 99), yang menyatakan bahwa "belajar merupakan suatu proses di mana organisma berubah perilakunya diakibatkan pengalaman". Berdasarkan kedua pendapat tersebut dapat dikatakan bahwa belajar mengarah kepada perubahan perilaku individu berdasarkan praktik atau pengalamannya. Dalam hal ini perilaku individu tidak akan berubah tanpa kegiatan praktik atau mengalami sesuatu kejadian atau pengalaman tertentu. Pendapat yang sama tentang definisi belajar dikemukakan oleh Syaiful Sagala (2005: 37) yang menyatakan bahwa, "belajar merupakan sebagai suatu proses perubahan perilaku atau peribadi seseorang berdasarkan praktik dan pengalaman tertentu". Hal yang sama juga dikatakan oleh Oemar Hamalik (2005: 37) bahwa, "belajar adalah suatu proses perubahan tingkah laku individu melalui interaksi dengan lingkungan".

Berdasarkan pendapat para tokoh tersebut dapat disimpulkan bahwa belajar merupakan suatu proses yang mengarah kepada perubahan perilaku individu berdasarkan praktik atau pengalamannya serta interaksi dengan lingkungannya. Bukanlah kegiatan belajar apabila tidak terjadai perubahan perilaku akibat dari praktik atau pengalaman. Dengan adanya proses belejar maka akan menghasilkan prestasi sebagai dampak dari perubahan perilaku hasil belajar tersebut.

Sehingga dapat dikatakan bahwa prestasi merupakan suatu hasil yang diperolah dari hasil 


\section{Didaktik : J urnal Pendidikan Guru Sekolah Dasar, ISSN : 2477-5673 \\ Sekolah Tinggi Keguruan dan IImu Pendidikan Subang Volume I Nomor 2, J uli 2016}

$\begin{array}{lrr}\text { perubahan } & \text { perilaku } & \text { dan } \\ \text { pengalamannya } & \text { dalam } & \text { proses }\end{array}$ pembelajaran. Hal ini sesuai dengan pendapat Syaiful Bahri Djamarah (1994: 20), yang menyatakan bahwa "prestasi adalah hasil dari suatu kegiatan yang telah dikerjakan, diciptakan, baik secara individual maupun kelompok. Prestasi tidak pernah dihasilkan selama seseorang tidak melakukan suatu kegiatan". Prestasi belajar merupakan bagian yang tidak terpisahkan dari kegiatan belajar dan sebagai out put atau hasil dari proses belajar tersebut, seperti halnya disampaikan oleh Moh Surya (1985: 174) yang menyatakan bahwa, "Prestasi belajar adalah seluruh kecakapan hasil yang dicapai diperoleh melalui proses belajar di sekolah yang dinyatakan dengan nilai-nilai prestasi berdasarkan hasil tes belajar". Sedangkan dalam Kamus Besar Bahasa Indonesia (2005: 700) dinyatakan, "Prestasi belajar adalah penguasaan pengetahuan atau keterampilan, yang dikembangkan oleh mata pelajaran, lazimnya ditujukan dengan nilai tes atau angka nilai yang diberikan oleh guru". Prestasi belajar menurut Abin Syamsudin (2004: 44) dapat diartikan yaitu "Kecakapan nyata atau aktual yang segera dapat didemonstrasikan dan diuji karena merupakan hasil usaha belajar yang bersangkutan dengan cara bahan yang terletak dijalankan".

Berdasarkan

beberapa pendapat di atas, dapat disimpulkan bahwa, prestasi belajar merupakan tingkat atau nilai akhir yang mencerminkan hasil belajar peserta didik yang dicapai melalui kriteria atau kurun waktu tertentu. Prestasi belajar dapat diukur dari capaian aspek kognitif, apektif maupun psikomotor ( civic knowledge, civic skill, dan civic disposition) yang dapat dicapai oleh peserta didik dalam mata pelajaran tertentu, salah satunya adalah mata pelajaran PKn. Dalam PP Nomor 32 Tahun 2013 Penjelasan Pasal 77 b Ayat (1) Pendidikan kewarganegaraan dimaksudkan untuk membentuk peserta didik menjadi manusia yang memiliki rasa kebangsaan dan cinta tanah air dalam konteks nilai dan moral Pancasila, kesadaran berkonstitusi Undang-Undang Dasar Negara Republik Indonesia 1945, nilai dan semangat Bhinneka Tunggal Ika, serta komitmen Negara Kesatuan Republik Indonesia.

Dalam buku guru PPKn Kelas XII (2015) berbunyi, secara umum tujuan mata pelajaran PPKn pada jenjang pendidikan dasar dan menengah adalah mengembangkan potensi peserta didik dalam seluruh komponen kewarganegaraan, yakni:

(1) Sikap kewarganegaraan termasuk keteguhan, komitmen dan, tanggung jawab kewarganegaraan (civic confidence, civic committment, and civic responsibility);

(2) Pengetahuan kewarganegaraan (civic knowledge);

(3) Keterampilan kewarganegaraan termasuk kecakapan dan partisipasi kewarganegaraan (civic competence and civic responsibility).

PKn sebagai pendidikan nilai dan moral bukanlah pengajaran yang berisikan konsep atau teori-teori belaka, tetapi secara lebih luas menanamkan berbagai hal yang ada hubungannya bangsa dan negara yang bertujuan untuk menjadikan warga negara yang memiliki wawasan kebangsaan dan cinta tanah air, serta untuk menjadikan warga negara yang baik ( to be good citizenship). Melalui pembelajaran PKn, peserta didik diarahkan dan 


\section{Didaktik : J urnal Pendidikan Guru Sekolah Dasar, ISSN : 2477-5673 \\ Sekolah Tinggi Keguruan dan IImu Pendidikan Subang Volume I Nomor 2, J uli 2016}

dibina bukan hanya dari segi pengetahuannya saja melainkan yang utama yaitu aspek penanaman sikap dan keterampilan, dan nilainilai luhur yang sesuai dengan falsafah bangsa dan negara. Berbagai materi pelajaran yang disajikan dalam PKn menjadi dasar pembinaan bagi peserta didik dalam melakukan berbagai aktivitas, baik di sekolah maupun dalam kehidupan bermasyarakat. Hal ini sesuai dengan pendapat Erwin S. (2015: 69) yang menyatakan bahwa "dalam mengembangkan karakter warga negara (civic disposition) di sekolah, PPKn sebagai program kurikuler mempunyai peran strategis untuk menanamkan pada siswa intisasi dari karakter atau waktak warga negara (civic disposition) yang didalamnya terkandung karakter privat yakni tanggungjawab moral, dispilin diri dan penghargaan terhadap harkat dan martabat manusia dari setiap individu adalah wajib".

Dari uraian di atas dapat disimpulkan bahwa PKn merupakan mata pelajaran yang sangat penting bagi peserta didik sebagai bekal dalam menjalankan kehidupannya menjadi warga negara yang baik, berakhlak mulia, bersikap pancasilais, demokratis dan bertanggunjawab. Pendidikan Kewarganegaraan dapat membekali peserta didik dengan budi pekerti, nilai dan moral serta pengetahuan, dan kemampuan dasar berkenaan dengan hubungan antar sesama warga negara maupun antara warga negara dengan negara serta pendidikan bela negara agar menjadi warga negara yang dapat diandalkan oleh bangsa dan negara dengan dilandasi oleh nilai-nilai kebangsaan dan cinta tanah air. Selain itu, PKn pada pendidikan dasar dan menengah berisikan pelajaran yang menekankan kepada pengalaman dan pembiasaan dalam kehidupan sederhana sebagai bekal untuk mengikuti pendidikan berikutnya guna mencapai prestasi belajar yang baik.

Upaya guru dalam mencapai tujuan di atas mermbutukan berbagai cara dan strategi agar tujuan pembelajaran PKn tersebut dapat tercapai. Proses pembelajaran PKn bertumpu sepenuhnya pada guru yang bersangkutan, yang ditunjang oleh berbagai kesiapan bahan ajar, metode, tujuan, evaluasi, media, juga pemahaman terhadap peserta didik, guna mengantarkan perserta didik mencapai prestasi yang baik. Menurut Uzer Usman (2005:21), peranan guru dalam meningkatkan proses belajar mengajar sekaligus sebagai upaya meningkatkan prestasi belajar peserta didik yaitu sebagai berikut:

Guru memiliki peran yang sangat penting dalam menentukan kuantitas dan kualitas pengajaran yang dilaksanakannya. Oleh sebab itu, guru harus memikirkan dan membuat perencanaan secara saksama dalam meningkatkan kesempatan belajar bagi peserta didiknya dan memperbaiki kualitas mengajarnya. Hal ini menuntut perubahan-perubahan dalam pengorganisasian kelas, penggunaan metode mengajar, strategi belajar-mengajar, maupun sikap dan karakteristik guru dalam mengelola proses belajar-mengajar.

Hal ini seperti dikemukakan Slameto (2003: 93) sebagai berikut. Guru akan mengajar efektif bila selalu membuat perencanaan sebelum mengajar. Dengan persiapan mengajar guru akan mantap di depan kelas, perencanaan yang matang dapat menimbulkan banyak inisiatif 
dan daya kreatif guru waktu mengajar, dapat meningkatkan interaksi belajar mengajar antara guru dan peserta didik.

Berdasarkan

pendapat-

pendapat di atas, dapat disimpulkan bahwa proses mengajar yang efektif harus direncanakan dengan baik, dan hal ini erat kaitannya dengan peningkatkan prestasi belajar. Artinya, pembelajaran yang efektif akan memberikan kemudahan bagi peserta didik dalam belajar serta menimbulkan motivasi belajar yang baik. Apabila kegiatan belajar peserta didik dilakukan dengan baik, tentunya akan menghasilkan prestasi belajar yang baik pula.

Upaya untuk meningkatkan prestasi belajar peserta didik dapat pula dilakukan dengan cara memberikan motivasi, tauladan, arahan dan pembinaan pola perilaku yang positif. Hal ini karena prestasi belajar peserta didik berawal dari motivasi, dan peniruan hal-hal yang dipandang baru oleh kalangan peserta didik. Aktivitas belajar peserta didik diwarnai oleh motivasi dan begitu kuat mempengaruhi sehingga dapat dikatakan bahwa motivasi memegang peranan penting dalam pelaksanaan pembelajaran. Selain itu penanaman sikap mandiri, disiplin, dan tanggungjawabpun sangat besar kontribusinya dalam menjembatani para peserta didik agar mencapai prestasi belajar yang maksimal.

Menurut Wina Sanjaya (2005: 28-30) mengemukakan bahwa upaya mengbangkitkan motivasi belajar peserta didik dapat dilakukan dengan hal-hal di bawah ini:

1) Memperjelas tujuan yang ingin dicapai.

2) Membangkitkan minat peserta didik.
3) Ciptakan suasana yang menyenangkan dalam belajar.

4) Berilah pujian yang wajar terhadap setiap keberhasilan peserta didik.

5) Berikan penilaian.

6) Berilah komentar terhadap hasil pekerjaan peserta didik.

7) Ciptakan persaingan dan kerja sama.

Hal tersebut di atas dapat disimpulkan bahwa membangkitkan motivasi bejalar peserta didik merupakan bagian dari upaya guru dalam meningkatkan prestasi belajar peserta didik. Apabila motivasi belajar ditingkatkan dengan baik, peserta didik akan belajar dengan baik pula, dan apabila belajar dilaksanakan dengan baik, maka akan menghasilkan prestasi belajar yang tinggi.

\section{HUBUNGAN DISIPLIN DENGAN PRESTASI BELAJAR}

Disiplin menurut The Liang Gie yang dikutif oleh E. Mulyasa (2001:5) yaitu "Suatu keadaan tertib di mana orang-orang yang tergabung dalam suatu organisasi tunduk pada peraturan-peraturan yang telah ada dengan rasa senang hati". Kedisiplinan sangat erat kaitannya dengan ketertiban dan kepatuhan terhadap peraturan yang ada disekitarnya yang disertai dengan kesadaran yang tinggi untuk menghormati dan mentaatinya. Disiplin lebih mengarah kepada kesadaran yang datang dari dalam diri dan bukan karena paksaan untuk melaksanakan tata tertib atau kaidahkaidah yang ada. Hal ini sesuai dengan pendapat $A$. Tabrani Rusyan (2003: 73) yang menyatakan bahwa "disiplin merupakan ketaatan atau kepatuhan, yaitu ketaatan seseorang terhadap tata tertib atau kaidah kaidah hidup lainnya". 


\section{Didaktik : J urnal Pendidikan G uru Sekolah Dasar, ISSN : 2477-5673 \\ Sekolah Tinggi Keguruan dan Ilmu Pendidikan Subang Volume I Nomor 2, J uli 2016}

Dari pendapat tersebut, dapat disimpulkan bahwa disiplin erat kaitannya dengan tertib atau melaksanakan ketertiban. Artinya, suatu keadaan di mana perilaku seseorang mengikuti pola-pola tertentu yang telah ditetapkan terlebih dahulu misalnya, apabila seseorang meminjam sesuatu pada orang lain, maka dia harus mengembalikan sesuatu itu pada waktu yang telah ditentukan". Orang yang hidup terbiasa dengan disiplin akan memiliki manfaat yang sangat besar dalam berbagai aspek kegiatan termasuk belajar peserta didik guna mencapai prestasi belajar yang lebih baik. Ketika belajar, peserta didik harus membiasakan hidup disiplin baik disiplin diri maupun disiplin sekolah, dan disiplin lingungani karena semua kegiatan yang dilakukan peserta didik akan terarah, tertib dan teratur apabila mereka membiasaakan untuk hidup berdisiplin. Selain itu, dengan disiplin semua kegiatan yang ada hubungannya dengan tugas belajar bisa dilaksanakan dengan efektif dan efisien. Bahkan dengan disiplin itu pula, kegiatan belajar yang sedang berlangsung memberikan suasana yang menyenangkan dan merangsang aktivitas belajar sehingga belajar tidak akan terasa membosankan.

Dari uraian di atas dapat disimpulkan bahwa disiplin belajar merupakan salah satu upaya dan perbuatan belajar untuk meningkatkan kualitas belajar guna mencapai prestasi belajar yang lebih baik. Hal-hal yang ada hubungannya dengan belajar dilaksanakan dengan tertib dan teratur sehingga menghasilkan prestasi belajar yang baik. Sikap disiplin pada dasarnya dimulai dari diri sendiri dan berawal dari lingkungan keluarga, masyarakat, teman bermain, dan lingkungan sekolah. $\mathrm{Di}$ dalam lingkungan keluarga, anak pertama kali memperoleh pendidikan, baik melalui keteladanan maupun nasihat atau pembinaan kebiasaan oleh kedua orang tua. Anak yang sejak kecil sudah berdisiplin, maka dimasa dewasanya akan tetap memiliki sikap disiplin yang tinggi karena sudah terbiasa dengan hidup taratur, dan tertib, sehingga kebiasaan itu akan merembet terhadap pola belajar dan sikap belajarnya disekolah. Hal tersebut akan memberikan dampak yang positif terhadap peningkatan prestasi belajar peserta didik. Disiplin merupakan bagian yang tidak terpisahkan dari norma-norma yang berlaku, baik di lingkungan keluarga, sekolah, atau lingkungan masyarakat. Orang yang mempunyai sikap disiplin tentunya dapat dibedakan dengan orang yang tidak berdisiplin. Karena itu, disiplin harus diterapkan dan dibiasakan kepada para peserta didik, hal ini sesuai dengan yang dikemukakan oleh A. Tabrani Rusyan (2003: 77) untuk membiasakan peserta didik disiplin dalam belajar, ada beberapa kegiatan yang dilakukan peserta didik melalui kebiasaan-kebiasaan sebagai berikut;

a. Membiasakan diri masuk kelas sesuai dengan jadwal yang telah ditetapkan.

b. Membiasakan diri melakukan berbagai kegiatan sesuai dengan petunjuk guru dan peraturan sekolah.

c. Membiasakan diri melaksanakan kebersihan kelas, halaman sekolah sebelum proses pembelajaran dimulai.

d. Membiasakan menjalankan tugas piket, untuk melatih tanggung jawab. 


\section{Didaktik : J urnal Pendidikan Guru Sekolah Dasar, ISSN : 2477-5673 \\ Sekolah Tinggi Keguruan dan Ilmu Pendidikan Subang Volume I Nomor 2, J uli 2016}

e. Membiasakan minta izin jika meninggalkan kelas untuk sesuatu keperluan.

f. Membiasakan diri mengirim surat kepada wali kelas jika berhalangan hadir atau tidak masuk sekolah.

g. mengucapkan salam kpada guru dan teman bila bertemu.

h. Membiasakan diri melakukan K3 setiap saat.

i. Pelaksanaan upacara bendera atau hari-hari nasional dengan tertib merupakan penerapan disiplin yang paling penting sebab pada upacara mengandung beberapa disiplin di antaranya tertib berbaris, terikat akan aturanaturan tata upacar bendera, membiasakan taat atau mematuhi aturan, melakukan dengan khidmat, melakukan tugas atau komando dengan tepat, menahan diri dan perasaan dengan terikat dan sikap bebas, dan mendengarkan dan menyimak isi amanat atau uraoan yang disampaikan pada waktu upacara.

Sedangkan prestasi belajar dalam pembelajaran $\mathrm{PKn}$ berupa perubahan pola perilaku dan moral peserta didik yang tadinya hidup asalasalan menjadi teratur dan tertib, tanggungjawab, dan berani membela kenenaran. Hal ini mutlak harus ditingkatkan sebab dapat memberikan manfaat yang sangat besar dalam peningkatan moral peserta didik. Prestasi belajar mencerminkan kemampuan dalam memahami dan menguasai serta sikap dan moral yang tinggi. Dan pembelajaran PKn merupakan mata pelajaran yang menekankan kepada pembentukan nilai, moral, sikap dan perilaku yang dapat dilihat dalam setiap kebiasaan hidupnya sertiap hari baik dilingkungan keluarga, rumah, masyarakat, sekolah bangsa dan negara.
Menurut E. Mulyasa (2001:21) dikatakan bahwa: Baik pendidikan moral maupun pendidikan nilai bertujuan membantu peserta didik untuk "berubah" sehingga mereka berperilaku dengan cara yang diterima dan produktif, baik secara pribadi maupun sosial. Perubahan perilaku terjadi sebagai akibat atau hasil pengalaman sehingga individu mengenal informasi baru yang menyebabkan adanya perubahan sikap, perilaku dan, moral.

Berdasarkan hal tersebut, prestasi belajar yang menekankan pada tatanan nilai, moral, dan perilaku yang baik harus mendapat perhatian yang serius dari guru sebagai dasar dan pedoman dalam melaksanakan proses pembelejaran dalam rangka peningkatan prestasi belajar peserta didik. Peningkatan prestasi belajar peserta didik harus disertai dengan disiplin. Kedisiplinan dalam belajar perlu dimiliki oleh peserta didik dalam mencapai prestasi belajar khususnya pada mata pelajaran PKn karena materi pelajaran yang disajikan dalam $\mathrm{PKn}$ menitikberatkan kepada pembinaan moral dan akhlak agar hidup tenang, tertib, nyaman dan teratur, dengan memiliki sikap demokratis dan bertanggungjawab. Hal ini jelas mempunyai hubungan yang erat antara nilai-nilai pada PKn dengan konsep disiplin bagi peserta didik. Disiplin dalam pembelajaran $\mathrm{PKn}$ akan memberikan pengaruh yang sangat besar terhadap penanaman nilai-niali moral atau aturan yang harus dilaksanakan dalam kehidupan sehari-hari setiap peserta didik.

Pembinaan kedisiplinan peserta dididk merupakan salah satu upaya untuk meningkatkan prestasi belajar para peserta didik melalui proses pembelajaran PKn disekolah, karena dengan disiplin segala kegiatan 
pembelajaran khususnya mata pelajaran PKn akan teratur dan terarah sehingga tujuan pembelajaran yang diharapkan dapat dicapai dengan baik. Oleh karena itu, disiplin sebagai salah satu upaya untuk meningkatkan prestasi belajar peserta didik dan hal tersebut harus dilaksanakan oleh para peserta didik, apabila menginginkan prestasi belajar yang lebih baik. Hal ini sedana dengan yang dikemukakan oleh $\mathrm{A}$. Tabrani Rusyan (2003:74) yaitu: "ketertiban dan keteraman dalam belajar tidak terwujud secara tibatiba, melainkan harus dilakukan secara terus-menerus, dan dibutuhkan sikap disiplin. Seseorang dapat disebut disiplin apabila ia melakukan atau mengerjakan sesuatu pekerjaan dengan tertib dan teratur sesuai dengan waktu dan ketentuan tanpa paksaan dari siapapun. Disiplin tersebut harus terwujud dalam kehidupan keluarga, masyarakat, termasuk di dalamnya disiplin di sekolah, disiplin belajar, dan mengerjakan tugas sekolah".

Dari pendapat tersebut di atas, dapat dikatakan bahwa peserta didik yang terbiasa hidup berdisiplin terntunya akan berprestasi tinggi karena dengan disiplin peserta didik dapat melaksanakan kegiatan belajar dengan baik. Disiplin dalam kegiatannya mampu meningkatkan kemampuan peserta didik dalam bertindak, berbuat, berpikir, dan belajar dengan aktif dan kreatif. Hidup disiplin pada dasarnya dapat dirasakan lebih aman, nyaman, tentram, dan damai serta teratur. Hal ini karena untuk memenuhi kebutuhan yang lebih baik perlu hidup teratur seperti dikemukakan oleh Soejono Seokanto (1991:80) yaitu: "manusia mempunyai kecenderungan yang sangat kuat untuk hidup teratur dalam memenuhi kebutuhan-kebutuhan dasarnya yang mencakup: sandang, pangan dan papan; keselamatan jiwa dan harta benda; kehormatan atau harga diri; kesempatan untuk mengembangkan kemampuan; dan kasih saying".

\section{METODE PENELITIAN}

Penelitian ini menggunakan metode studi deskriptif dengan pendekatan kuantitatif. Pengumpulan data dengan menggunakan teknik angket, dan ditunjang dengan wawancara, studi dokumentasi, serta studi pustaka. Dengan populasi sebanyak 432 orang peserta didik, dan 2 orang guru. Sampel dalam penelitian ini diambil $25 \%$ dari jumlah populasi yaitu sebanyak 108 orang peserta didik dan 2 orang guru SMK Pasundan I Subang.

\section{PEMBAHASAN HASIL PENELITIAN}

Berdasarkan hasil pengolahan data dalam penelitian ini dapat dikatakan hubungan antara kedisiplinan peserta didik dengan prestasi belajar peserta didik pada mata pelaajran PPKn dapat dikategorikan tinggi yaitu sebesar 0 , 832. Hal ini dapat disimpulkan bahwa terdapat hubungan yang signifikan antara kedisiplinan peserta didik dengan prestasi belajar peserta didik pada mata pelajaran PPKn di SMK Pasundan 1 Subang, dan Jika kesiplinan peserta didik tinggi, maka prestasi belajar peserta didikpun akan tinggi, sebagaimana digambarkan dalam gambar di bawah ini:

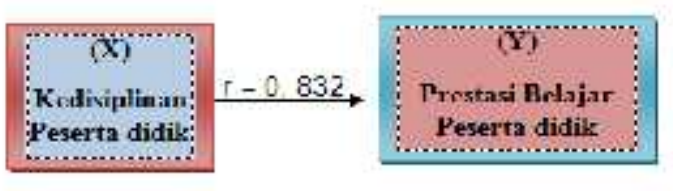


Berdasarkan hasil analisis data angket maupun hasil wawancara dan observasi menunjukkan bahwa prestasi belajar peserta didik di SMK Pasundan 1 Subang cukup tinggi. Tingkat disiplin peserta didik cukup baik yang tercermin dalam melaksanakan tata tertib sekolah, membiasakan disiplin dalam belajar, dan kebiasaan hidup dalam lingkungan keluarga, dan tercermin dalam aktivitasnya selama proses pembelajaran disekolah. Semakin baik prestasi yang dicapai peserta didik, maka semakin tinggi pula tingkat disipin yang mereka laksanakan. Prestasi belajar dengan tingkat disiplin peserta didik mempunyai hubungan yang erat.

Pelaksanaan disiplin yang tercermin dalam melaksanakan tata tertib sekolah merupakan bukti konkret bahwa peserta didik patuh terhadap peraturan yang telah ditentukan. Dalam hal ini peserta didik melaksanakan tata tertib tanpa adanya paksaan, melainkan benarbenar tulus untuk dikerjakan dengan sebaik-baiknya. Dengan adanya tata tertib sekolah, peserta didik mempunyai sikap dan perilaku yang baik sehingga aktif dan kreatif dalam belajar yang pada akhirnya dapat mengerjakan tugas-tugas, ujian akhir semester dan ujian kenaikan kelas serta ujian sekolah dan ujian nasional dapat dilakukan dengan baik.

Untuk mencapai prestasi yang baik, peserta didik perlu disiplin dalam belajar. Prestasi yang baik sangat ditentukan oleh tingkat disiplin dalam belajar. Artinya, dengan belajar yang baik, teratur, tertib, nyaman dan penuh tanggung jawab serta dengan dilandasi dengan kesadaran yang tinggi, maka akan berpengaruh terhadap kelancaran dalam melaksaksanakan berbagai tugas yang berikan oleh guru. Selain itu, dengan disiplin belajar yang tinggi pula, maka peserta didik akan lancar dalam melaksanakan ujian akhir semester dan ujian kenaikan kelas sehingga dapat mencapai nilai yang sangat baik.

Bentuk disiplin dalam lingkungan keluarga merupakan aplikasi dari pembinaan moral di sekolah dan dukungan pendidikan keluarga serta begitupun sebaliknya. Hal tersebut sangat erat kaitannya dengan sikap dan perilaku yang perlu dilakukan oleh peserta didik dalam kehidupan sehari-hari. Artinya, pelaksanaan disiplin oleh peserta didik di lingkungan sekolah harus diterapkan pula di luar lingkungan sekolah sebagai perwujudan bahwa pelaksanaan disiplin bukan karena paksaan, melainkan karena kesadaran sendiri, dan begitupun sebaliknya kebiasaan hidup disiplin dirumahpun harus mampu diaplikasikan didalam lingkungan sekolah, sehingga terjadi sinergitas antara pembinaan kedisiplinan peserta didik dilingungan keluarga dengan pembinaan kedisiplinan peserta didik dilingkungan sekolah. Sehubungan dengan hal tersebut, maka disiplin yang tinggi dalam lingkungan keluarga berpengaruh terhadap kegiatan belajar sehingga ada hubungan antara disiplin dalam keluarga dengan prestasi belajar yang dicapai peserta didik di sekolah.

\section{KESIMPULAN}

Kedisiplinan peserta didik menentukan prestasi belajar yang dicapai peserta didik pada Mata Pelajaran PKn. Hal ini tercermin dalam nilai-nilai yang dicapai peserta didik melalui tugas-tugas, nilai-nilai Ujian Akhir Semester, Ujian Kenaikan Kelas, Ujian Sekolah, dan Ujian Nasional. Selain itu wujud 
ketercapaian prestasi belajar peserta didik pada mata pelajaran PKn terwujud dari adanya kebiasaan hidup peserta didik yang disiplin, tanggungjawab, teratur, dan tertib, serta selalu taat terhadap aturan baik dilingkungan keluarganya, maupun lingkungan sekolah. Selain itu tingkat kedisiplinan peserta didik tercermin dalam melaksanakan tata tertib sekolah, membiasakan disiplin dalam belajar, dan kebiasaan hidup teratur dalam lingkungan keluarga. Terdapat hubungan antara kedisiplinan peserta didik dengan prestasi belajar peserta didik dalam mata pelajaran PKn. Semakin baik peserta didik dalam kedisiplinannya maka prestasi belajarnyapun akan semakin tinggi.

\section{DAFTAR PUSTAKA}

Ali, H. Muhammad. 2002. Guru dalam Proses Belajar Mengajar. Bandung: Sinar Baru Algensindo Offset.

Arikunto, Suharsimi. 1998. Prosedur Penelitian. Jakarta: Rineka Cipta.

D. Soemarno, 1996. Gerakan Disiplin Nasional. Jakarta: CV. Mini Jaya Abadi.

Hamalik, Oemar. 2005. Kurikulum dan Pembelajaran. Jakarta: Bumi Aksara.

Lemhannas, 1997. Disiplin Nasional. Jakarta: PT. Balai Pustaka.

Makmun, Abin Syamsudin. 2004. Psikoligi Kependidikan. Bandung: Remadja Rosda Karya.

Pemerintah Propinsi DT. 1 Jawa Barat. 1996. Gerakan Disiplin Nasional. Bandung.

Purwanto, Ngalim. 1993. Psikologi Pendidikan. Bandung: Rosdakarya.

Rusyan, A. Tabrani. 2003.
Pendidikan Budi Pekerti. Jakarta: Intimedia.

Sagala, Syaiful. 2005. Konsep dan Makna Pembelajaran. Bandung: Alfabeta.

Sanjaya, Wina. 2006. Strategi Pembelajaran. Jakarta: Prenada Kencana Media.

Slameto. 2003. Belajar dan Faktorfaktor yang Mempengaruhinya. Jakarta: Rineka Cipta.

Soegeng Prijodarminto. 1993. Disiplin Kita Menuju Sukses. Jakarta: $\mathrm{PT}>$ Pradnya Paramita.

Soerjono Soekanto dan Mustafa Abdullah, 1982. Sosiologi Hukum Dalam Masyarakat, Jakarta: Rajawali Press.

Soerjono Soekanto, 1982. Kesadaran Hukum dan Kepatuhan Hukum, Jakarta: Rajawali Press.

Sumarsono dkk. 2005. Pendidikan Kewarganegaraan. Jakarta: Gramedia Pustaka Utama.

Surya, Moh. 1985. Psikologi Pendidikan. Bandung: IKIP Bandung.

Susanto, Erwin, 2015. Pengaruh Pembelajaran Habituasi dan Ekstrakurikuler Terhadap Pembentukan Civic Disposition Siswa SMA Negeri Se-Kota Bandar Lampung. Jurnal Mimbar Demokrasi. (10) hlm. 66-69.

Syah Muhibin. 2000. Psikologi Pendidikan dengan

Pendekatan Baru. Bandung: Remajda Roskarya.

Thabrani Rusyan. (1996). Memasyarakatkan Dsiisplin dan Mendisiplinkan Masyarakat. Jawa Barat: Suara daerah 309. PD TK I.

Undang-Undang Republik Indonesia Nomor 20 Tahun 2003 tentang Sistem Pendidikan Nasional.

Usman, Moh. Uzer. 2005. Menjadi Guru Profesional. Bandung: 
Didaktik : J urnal Pendidikan Guru Sekolah Dasar, ISSN : 2477-5673

Sekolah Tinggi Keguruan dan IImu Pendidikan Subang Volume I Nomor 2, J uli 2016

Remadja Rosda Karya.

W.J.S Poewadarminta. 1987. Kamus

Umum Bahasa Indonesia. Jakarta: Balai Pustaka.

Winataputra, Udin S. dkk. 2002.
Pedoman Umum Pendidikan Budi Pekerti pada Jenjang Pendidikan Dasar dan Menengah. Jakarta Depdikbud. 